\title{
Stem volume estimate using an allometric equation model: a case study of Acer monspessulanum stands in Tunisia
}

\author{
Estimativa volumétrica do fuste usando um modelo de equação alométrica: \\ um estudo de caso de povoamentos de Acer monspessulanum na Tunísia

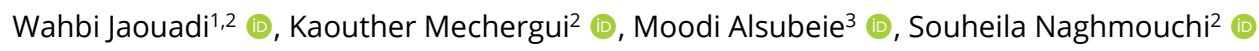 \\ 'Silvo-Pastoral Institute of Tabarka, University of Jendouba, Jendouba, Tunisia \\ ${ }^{2}$ National Institute of Research in Rural Engineering, Waters and Forests, University of Carthage, Ariana, Tunisia \\ ${ }^{3}$ Biology Department, College of Sciences, Imam Muhammed bin Saud Islamic University, Riyadh, Kingdom of Saudi Arabia
}

How to cite: Jaouadi, W., Mechergui, K., Alsubeie, M., \& Naghmouchi, S. (2020). Stem volume estimate using an allometric equation model: a case study of Acer monspessulanum stands in Tunisia. Scientia Forestalis, 48(126), e3318. https://doi.org/10.18671/scifor.v48n126.24

\begin{abstract}
Allometric relationships for estimating stem volumes of Acer monspessulanum trees were investigated in Jebel Serej National Park. Several allometric relationships between stem volume and different dimensions were tested and the coefficient of determination $\mathrm{R}^{2}$ values were used to compare the strength of the relationships. Although the allometric equations have been highly significant $(P<0.01)$ there was considerable variation among them as indicated by the $\mathrm{R}^{2}$ values. Our results suggested that tree volume is more correlated with basal area than with simple $\mathrm{DBH}$. The allometric relationships of stem volume to the tree diameter at $10 \%$ of tree height $\left(D_{0.1}\right)$ did not improve the allometric strength in comparison with simple $\mathrm{DBH}$ as reported in case of some other tree species. The multiplication of tree height $\mathrm{H}$ with $\mathrm{DBH}$ in the allometric equation gives a little improvement in the degree of fitness of the allometric equations. However, for the Acer stands studied the stem dbh alone showed a very strong accu racy of estimation $\left(R^{2}=0.969\right)$ especially when used as $D_{1.3}{ }^{2}$ and $D_{0.1}{ }^{2}$. It is concluded that the use of tree height in the allometric equation can be neglected for the species, as far as the present study area is concerned. Therefore, for estimating the stem volume of Acer, the use of $D_{1.3^{2}}$ and $D_{0.1}{ }^{2}$ as an independent variable in the allometric equation with a cubic equation is recommended. This paper describes details of tree volume allometry, which is important for the application and planning of silvicultural treatments and wood forest production.
\end{abstract}

Keywords: Stem volume; Modeling; Mediterranean forest; Acer; National park.

\section{Resumo}

Relações alométricas para estimar os volumes de fustes de árvores Acer monspessulanum foram investigadas no Parque Nacional Jebel Serej. Várias relações alométricas entre o volume do fuste haste e diferentes dimensões foram testadas e os valores do coeficiente de determinação $\mathrm{R}^{2}$ foram usados para comparar modelos ajustados. Embora as equações alométricas fossem altamente significativas $(P<0,01)$, houve considerável variação entre elas, conforme indicado pelos valores de $\mathrm{R}^{2}$. Nossos resultados sugerem que o volume de árvores está mais correlacionado com a área basal do que com o DAP. As relações alométricas do volume do fuste com o diâmetro a $10 \%$ da altura da árvore $\left(D_{0.1}\right)$ não melhoraram a robustez alométrica em comparação com o DAP, como relatado no caso de algumas outras espécies de árvores. A multiplicação da altura da árvore $\mathrm{H}$ pelo DAP da equação alométrica propicia uma pequena melhoria no ajuste das equações alométricas. No entanto, para povoamentos de Acer, o DAP do fuste sozinho mostrou uma acurácia muito alta na estimativa $\left(R^{2}=0,969\right)$, especialmente quando usado como $D A P^{2}$ e $D_{0,1}^{2}$. Concluise que o uso da altura das árvores na equação alométrica pode ser negligenciado para a espécie, no que se

Financial support: None.

Conflict of interest: Nothing to declare.

Corresponding author: jaouadiwahbi@gmail.com

Received: 19 March 2019.

Accepted: 22 July 2019.

Editor: Francides Gomes da Silva Júnior.

(c) This is an Open Access article distributed under the terms of the Creative Commons Attribution License, which permits unrestricted use, distribution, and reproduction in any medium, provided the original work is properly cited. 
refere à área de estudo atual. Portanto, para estimar o volume do fuste de Acer, recomenda-se o uso de $\mathrm{DAP}^{2}$ e $\mathrm{D}^{2}{ }_{0.1}$ como variável independente na equação alométrica com uma equação cúbica. Este artigo descreve detalhes da alometria de volume de árvores, o qual é importante no manejo florestal.

Palavras-chave: Volume do fuste; Modelagem; Floresta mediterrânea; Acer; Parque nacional.

\section{INTRODUCTION}

The Acer genus consists of 120 to 156 species, including deciduous and evergreen species (Van Gelderen et al., 1994; Dirr, 2009; Grimshaw \& Bayton, 2009). Acer species are found in many types of climates and landscape types in Europe, North Africa, Asia, and North America from dry steppe environments in southeastern Europe to moist and rich forest habitats in China and eastern North America (Mechergui et al., 2018). Published inventories (Raupp et al., 2006; Sjöman et al., 2012; Cowett \& Bassuk, 2014) indicate that Acer are routinely used across the temperate world but the range of species used is commonly restricted to just a few traditional species. Sjöman et al. (2015) confirm the wide range of tolerance to water deficits in Acer and give an important insight into the potential of species to tolerate periods of low water availability by providing quantitative data not previously available.

Acer, a particular species in China, is an important widespread prominent species in the hardwood forests from north to west China, and widely planted as landscape trees for its brilliant leaf color in autumn. Drought stress had both significantly reduced growth and physiology of Shantung Acer (A. truncatum Bunge) seedlings (Li et al., 2015). It is mainly found in sub-Mediterranean or sub-Atlantic mixed forests on soils with high lime content, but it can grow on acid substrates as well. It is adapted to grow on poor and shallow soils and can tolerate drought periods. One of the species is A. monspessulanum, which constitutes a part of a very sparse complex of open xeromorphic scrub (Zohary, 1973).

A. monspessulanum L. is known by local names: bordo do Montpellier (Portuguese), arce de Montpellier (Spanish), érable de Montpellier (French) and Montpellier maple (English). In Tunisia its name is "Doull"; it is a sacred tree in Jebel Serej national park (Mechergui et al., 2018). In Tunisia the Acer species is located in the mountain range of the forest reserve in the Tunisian ridge (Jebel Serej National Park). The forest reserve serves as a natural training laboratory for the advancement of technical knowledge related to the conservation of the forest, its biodiversity and other resources (Pagaduan \& Afuang, 2012).

In order to manage Mediterranean forests in a sustainable manner, the estimates of the growing stock, such as volume biomass estimates, are required (Lumbers et al., 2016). Foresters traditionally derive timber volumes by employing allometric techniques. Allometric relationship for estimating stand volume as well as forest biomass is very important for managing natural and artificial forest resources (Baker et al., 2004; Chave et al., 2005; Malhi et al., 2006; Nogueira et al., 2008).

To obtain an estimate of the stem volume of standing trees, investigators usually measure the diameter of the tree at several heights up the trunk or, for species that are well studied, integrate mathematical taper functions (Philip, 1994; Robinson \& Wood, 1994; Akindele \& LeMay, 2006). Subedi et al. (2011) recommended a stem taper equation as one of the most accurate tools to predict stem diameter and volume to any height of a standing tree. In the estimation of stand volume, the uncertainties appear due to the measurements of basal area and the use of a mean form factor, which is related to mean tapering (Nogueira et al., 2008). Thus, allometric relationships offer better estimates of the forest standing volume, which is also an important parameter in further research such as biomass and carbonemission estimates avoiding the uncertainties in the bole volume estimates (Ketterings et al., 2001; Nogueira et al., 2008). Therefore, choosing a suitable functional variable in the allometric equation is very important for allometric techniques in forest science (Ketterings et al., 2001; Khan et al., 2005). There are various independent variables in the allometric relationships to estimate biomass. In most studies, the allometric equation was taken as the only independent variable (Nakasuga, 1979; Putz \& Chan, 1986; Clough \& Scott, 1989; Amarasinghe \& Balasubramaniam, 1992; Clough et al., 1997; Ong et al., 2004). 
However, incorporation of the variable $\mathrm{H}$ (tree height i.e., the use of $\mathrm{D}^{2} \mathrm{H}$ ) ensures a higher accuracy of the allometric estimation in some tree species (Suzuki \& Tagawa, 1983; Tamai et al., 1986; Kusmana et al., 1992; Poungparn et al., 2002). Moreover, the use of the new variable $D_{0.1}{ }^{2}$ $H\left(D_{0.1}\right.$, diameter at one-tenth of $H$ ) instead of $D_{1.3}{ }^{2} \mathrm{H}$ has been suggested to improve the accuracy of estimation (Ogawa \& Kira, 1977; Hagihara et al., 1993; Khan et al., 2005).

The allometric equations developed from various species yield useful estimates for largescale inventories. Tree volume is more correlated with basal area than with simple DBH (stem diameter at $1.3 \mathrm{~m}$ height above the ground). The multiplication of tree height $\mathrm{H}$ by DBH in the allometric equation gives a small improvement to the degree of fitness of the allometric equations (Khan \& Faruque, 2010). However, for Sissoo plantations studied the stem dbh alone showed a very strong accuracy of estimation $\left(R^{2}=0.997\right)$ especially when used as $D^{2}$ (Khan \& Faruque, 2010). In this paper, we seek to establish the allometric relationships of the stem volume of individual trees to different stem positions, such as $\mathrm{D}_{1.3}, \mathrm{D}_{1.3}{ }^{2}, \mathrm{D}_{1.3}{ }^{2} \mathrm{H}, \mathrm{D}_{0.1}, \mathrm{D}_{0.1}{ }^{2}$ and $\mathrm{D}_{0.1}{ }^{2} \mathrm{H}$ and to propose a standard method for predicting the stem volume of Acer. Since cutting or harvesting trees is strictly prohibited in the study site because it is located within a national park, the aim of this study was to develop stem models without felling trees and without causing indelible damage to the tree or to the nearby understory. The scope of this study involves an important tree species in the Jebel Serej National Park.

\section{MATERIALS AND METHODS}

\section{Study site}

The Jebel Serej (Figure 1) is a limestone mountain located in the center of Tunisia, within the Tunisian ridge. It rises to 1357 meters above sea level. The mountain is located at $35^{\circ} 56^{\prime}$ $12.12^{\prime \prime} \mathrm{N}, 9^{\circ} 32^{\prime} 58.92 "$ E. Jebel Serej is located twenty kilometers southeast of Siliana and sixty kilometers north-west of Kairouan, in the middle of the ridge, halfway between Grombalia and Jebel Tamsmida. It is about five kilometers wide and twenty kilometers long. The origin of the appellation serej comes from the peculiar shape of a mountain ridge which approaches the shape of a saddle. This rapprochement has fed many legends and myths around the formation of this singularity among the neighboring populations of the jebel. The mountain lies in the Jebel Serej National Park. This mountain is considered a special place for speleology in Tunisia due to the Ain Dhab and Mine caves in the mountain. The mountain has been protected within the Jebel Serej National Park by a decree of March 29, 2010.

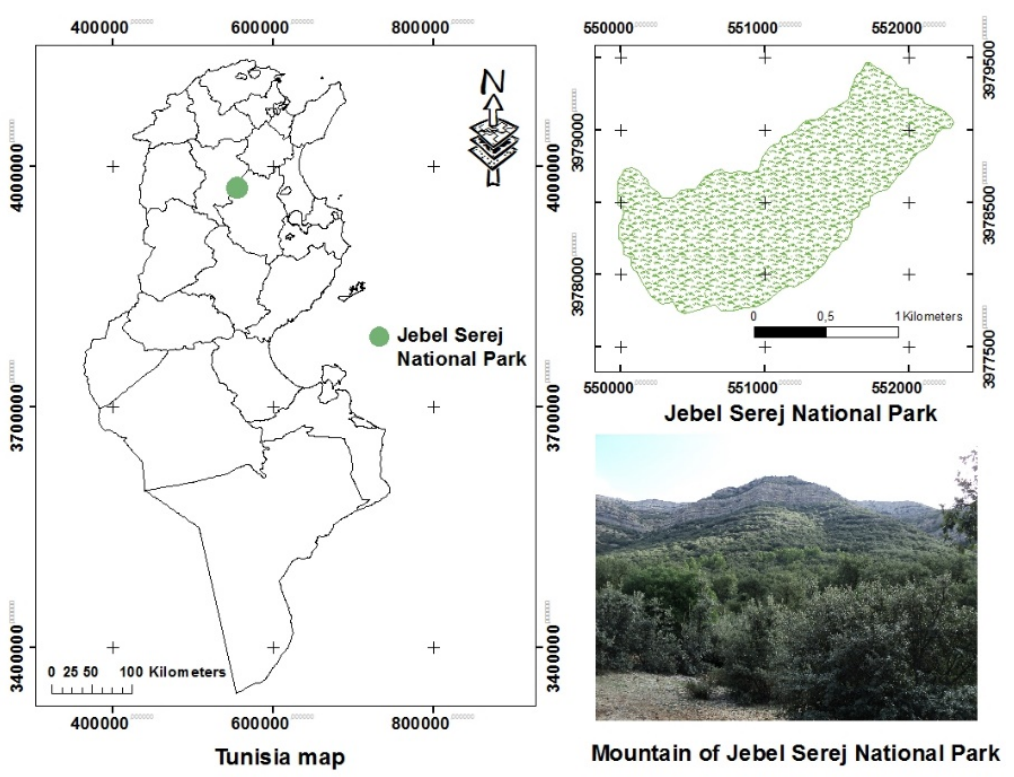

Figure 1. Location of Jebel Serej National Park. 
The park is located in the semi-arid upper bioclimatic stage with a fresh climate. The park is located in a matorral of Pinus halepensis with Quercus ilex and Acer monspessulanum. The dense forest layer is constituted by the Aleppo pine in the lower part. This stratum is sparse at this altitude where it is represented by Acer monspessulanum. Among the constituents of the shrub layer are: Quercus ilex, Phillyeria latifolia, Calicotome villosa, Juniperus oxycedrus, Tamus communis, Crataegus azarolus, Ampelodesma mauritanica, Astragalus armatus and Cytisus villosus. The originality of the flora of this national park is marked by the presence of Acer monspessulanum. Some trees are more than $100 \mathrm{~cm}$ in diameter.

The Jebel Serej is also distinguished by the presence on decarbonated soil of a stand of Quercus suber constituting a particular sub-association in a fresh forest environment. Another remarkable feature of the Serej is related to its geological nature and lies in the existence of several caves and natural cavities that constitute one of the attractions of the limestone massif of Jebel Serej. As in any mountain range, the cliffs are omnipresent and are the refuge of many nesting birds of prey and other species of birds. Among the first ones are the peregrine falcon (Falco peregrinus), the lantern falcon (Falco biarmicus), the bonelli's eagle (Aquila fasciata), the fierce buzzard (Buteo rufinus), the booted eagle (Hieraaetuspennatus) and the Egyptian vulture (Neophron percnopterus). In its cliffs are also found the Alpine Swift (Apus melba), the Black Swift (Apus apus), the Bluebird (Monticola solitarius), the Mushroom Rubetta (Phoenicurus moussieri) and the Red Black Tail (Phoenicurus ochruros).

\section{Sampling, data collection and analysis}

Thirty individual trees of Acer at Djebel Serej National Park were used for this study with a wide range of diameter and height (Table 1). The following measurements were carried out: tree height $H$, stem diameter at $10 \%$ of the total height of the tree $\left(D_{0.1}\right.$ - Khan et al., 2005), stem $\mathrm{DBH}$ at $\mathrm{D}_{1.3}$ and stem diameter at $1.0 \mathrm{~m}$ intervals and thereafter up to a thick wood height (stem height at $07 \mathrm{~cm}$ diameter). The height was measured using a Vertex hypsometer (Haglof, Sweden). For measuring the diameter, girth values were transformed to diameter after being divided by $\pi$. From the girth measurements made at each meter of converted standing trees using Bitterlich's relascope, the volume of thick wood as well as the total volume of each stem was cubed by summation of the volumes $(v)$ of the successive parts of wood.

Table 1. Description of Montpellier Maple (Acer monspessulanum) sample trees used for this study. $H$ : Tree height; $D_{0.1}$ : stem diameter at a height of $H / 10 ; D_{1.3}$ : stem diameter at $1.3 \mathrm{~m}$ height (dbh); $V$ : stem volume.

\begin{tabular}{cccccccccc}
\hline $\begin{array}{c}\text { Tree } \\
\text { No. }\end{array}$ & $\begin{array}{c}\mathbf{D}_{\mathbf{1 . 3}} \\
\mathbf{( c m})\end{array}$ & $\begin{array}{c}\mathbf{D}_{\mathbf{0 . 1}} \\
\mathbf{( c m})\end{array}$ & $\begin{array}{c}\mathbf{H} \\
\mathbf{( m )}\end{array}$ & $\mathbf{V}\left(\mathbf{c m}^{\mathbf{3}}\right)$ & $\begin{array}{c}\text { Tree } \\
\mathbf{N o} .\end{array}$ & $\begin{array}{c}\mathbf{D}_{\mathbf{1 . 3}} \\
\mathbf{( c m})\end{array}$ & $\begin{array}{c}\mathbf{D}_{\mathbf{0 . 1}} \\
(\mathbf{c m})\end{array}$ & $\begin{array}{c}\mathbf{H} \\
(\mathbf{m})\end{array}$ & $\mathbf{V}(\mathbf{c m} \mathbf{3})$ \\
\hline 1 & 22.970 & 23.210 & 4.850 & 17343.195 & 16 & 65.471 & 65.970 & 4.750 & 67394.759 \\
2 & 24.190 & 24.750 & 4.120 & 24701.999 & 17 & 75.110 & 75.870 & 4.540 & 96372.551 \\
3 & 26.210 & 26.510 & 3.950 & 32865.221 & 18 & 80.140 & 81.570 & 5.450 & 108229.769 \\
4 & 31.286 & 31.740 & 4.100 & 27061.630 & 19 & 85.190 & 85.850 & 5.750 & 135393.083 \\
5 & 36.330 & 37.380 & 3.580 & 21009.242 & 20 & 91.220 & 91.520 & 5.790 & 146952.960 \\
6 & 38.470 & 39.320 & 3.690 & 46101.742 & 21 & 119.230 & 119.780 & 5.420 & 129431.900 \\
7 & 40.530 & 40.890 & 3.680 & 44218.196 & 22 & 120.250 & 121.650 & 5.630 & 211576.741 \\
8 & 42.760 & 42.920 & 3.750 & 45365.843 & 23 & 129.280 & 129.460 & 5.420 & 418704.911 \\
9 & 43.923 & 44.340 & 3.450 & 48882.666 & 24 & 132.180 & 132.840 & 5.230 & 398571.234 \\
10 & 45.923 & 45.870 & 3.760 & 53938.790 & 25 & 154.270 & 154.980 & 4.580 & 444227.833 \\
11 & 48.878 & 49.850 & 3.730 & 58796.399 & 26 & 165.290 & 166.050 & 5.750 & 576925.522 \\
12 & 49.197 & 49.580 & 4.240 & 71802.654 & 27 & 180.382 & 180.670 & 6.370 & 672226.244 \\
13 & 52.220 & 52.780 & 4.650 & 63070.901 & 28 & 195.440 & 196.870 & 6.350 & 609402.202 \\
14 & 55.515 & 55.930 & 4.450 & 64712.317 & 29 & 198.337 & 198.860 & 6.530 & 656770.991 \\
15 & 63.152 & 63.670 & 4.780 & 44201.649 & 30 & 215.656 & 215.970 & 6.540 & 681236.500 \\
\hline
\end{tabular}


These parts of wood are assimilated to truncated cone formula (Van Coillie et al., 2016) and cubed by the formula:

$V=\pi h / 12\left(d 0^{2}+d 0 d s+d s^{2}\right)$

In which:

$\mathrm{h}=$ length of the part of wood,

$\mathrm{d} 0=$ girth at the base of the part of wood,

$\mathrm{ds}=$ girth end of the part of wood

In this study, the allometric relationships of the volume and different stem positions such as $D_{1.3}, D_{1.3}^{2}, D_{1.3}{ }^{2} H, D_{0.1}, D_{0.1}{ }^{2}$ and $D_{0.1}{ }^{2} \mathrm{H}$ were also established using the equations in Table 2 . By comparing 10 commonly used models (Table 2) provided by the (SPSS 23.0) software package (Statistical Package for the Social Science, 2004) (i.e., linear, logarithmic, inverse, quadric, cubic, power, compound, sigmoidal, growth, and exponential) using the coefficient of determination $\left(R^{2}\right)$. The coefficient of determination $R^{2}$ was calculated using the following equation (based on the real data before logarithmic transformation):

$R^{2}=1-\frac{\sum_{i=1}^{n}\left(y_{i}-\hat{y}_{i}\right)^{2}}{\sum_{i=1}^{n}\left(y_{i}-\bar{y}_{i}\right)^{2}}$

where $y i$ is the observed value, $\hat{y}_{i}$ is the corresponding values estimated from the regression line, and $\bar{Y}$ is the mean of the observed values (Kvalseth, 1983). The $\mathrm{R}^{2}$ value (coefficient of determination) is a measure of the goodness-of-fit between the observed and calculated values (Khan et al., 2005).

Table 2. Ten common models and their parameters and model fits for Acer monspessulanum.

\begin{tabular}{ccc} 
& Model & Expression \\
\hline 01 & Linear & $\mathrm{Y}=\mathrm{a}+(\mathrm{bx})$ \\
02 & Logarithmic & $\mathrm{Y}=\mathrm{a}+(\mathrm{b} \ln (\mathrm{x}))$ \\
03 & Inverse & $\mathrm{Y}=\mathrm{a}+(\mathrm{b} / \mathrm{x})$ \\
04 & Quadratic & $\mathrm{Y}=\mathrm{a}+(\mathrm{bx})+\left(\mathrm{cx}^{2}\right)$ \\
05 & Cubic & $\mathrm{Y}=\mathrm{a}+(\mathrm{bx})+\left(\mathrm{cx}^{2}\right)+\left(\mathrm{d} \mathrm{x}^{3}\right)$ \\
06 & Power & $\mathrm{Y}=\mathrm{a}\left(\mathrm{x}^{\mathrm{b}}\right)$ \\
07 & Compound & $\left.\mathrm{Y}=\mathrm{a}(\mathrm{b})^{\mathrm{x}}\right)$ \\
08 & S-curve & $\mathrm{Y}=\mathrm{e}^{(\mathrm{a}+(\mathrm{b} / \mathrm{x}))}$ \\
09 & Growth & $\mathrm{Y}=\mathrm{e}^{(\mathrm{a}+(\mathrm{bx}))}$ \\
10 & Exponential & $\mathrm{Y}=\mathrm{a}\left(\mathrm{e}^{(\mathrm{bx})}\right)$
\end{tabular}

Again, the fitting performance of the selected models was evaluated by examining values adjusted coefficient of determination $\left(R^{2}{ }_{\text {adj }}\right)$ :

Adjusted coefficient of determination:

$R_{a d j}^{2}=1-\frac{(n-1) \sum_{i=1}^{n}\left(y_{i}-\hat{y}_{i}\right)^{2}}{(n-p) \sum_{i=1}^{n}\left(y_{i}-\bar{y}_{i}\right)^{2}}$

Where $n$ is the number of observations, $y_{i}, \hat{y}_{i}$ and $\bar{y}_{i}$ are the measured, predicted and average values of the dependent variable and $p$ is the number of free parameters estimated within the model. 
The adjusted coefficient of determination represents the share of variability of the dependent variable that is explained by the regression taking into account the number of parameters $\mathrm{p}$ in the model ( $\mathrm{n}$ being the number of observations). The adjusted coefficient of determination $\mathrm{R}_{\text {adj }}^{2}$ is used in place of the ordinary coefficient of determination $\mathrm{R}^{2}$ to compare models with a different number of parameters (Palm, 1988). Summary statistics for the used data set are represented in Table 3. Stem volume varied between 17343.195 and $681236.5 \mathrm{~cm}^{3}$. DBH varied between 22.970 and $215.656 \mathrm{~cm}$.

Table 3. Descriptive Statistics for the data set used for modelling.

\begin{tabular}{|c|c|c|c|c|c|c|}
\hline \multirow{2}{*}{ Variable } & \multirow{2}{*}{$\begin{array}{l}\text { Minimum } \\
\text { Statistic }\end{array}$} & \multirow{2}{*}{$\begin{array}{l}\text { Maximum } \\
\text { Statistic }\end{array}$} & \multicolumn{2}{|c|}{ Mean } & \multirow{2}{*}{$\begin{array}{c}\text { Std. } \\
\text { Deviation } \\
\text { Statistic }\end{array}$} & \multirow{2}{*}{$\begin{array}{l}\text { Variance } \\
\text { Statistic }\end{array}$} \\
\hline & & & Statistic & Std. Error & & \\
\hline $\mathrm{D}_{1.3}(\mathrm{~cm})$ & 22.970 & 215.656 & 87.633 & 10.710 & 58.661 & 3441.210 \\
\hline $\mathrm{D}_{1.3^{2}}\left(\mathrm{~cm}^{2}\right)$ & 527.621 & 46507.510 & 11006.104 & 2440.231 & 13365.699 & 178641910.017 \\
\hline $\mathrm{D}_{0.1}(\mathrm{~cm})$ & 23.210 & 215.970 & 88.221 & 10.723 & 58.736 & 3449.921 \\
\hline $\mathrm{D}_{0.1^{2}}\left(\mathrm{~cm}^{2}\right)$ & 538.704 & 46643.041 & 11117.986 & 2454.427 & 13443.452 & 180726412.994 \\
\hline $\mathrm{H}(\mathrm{m})$ & 3.450 & 6.540 & 4.829 & 0.176 & 0.966 & 0.934 \\
\hline $\begin{array}{l}\mathrm{D}_{1.3^{2}} \cdot \mathrm{H} \\
\left(\mathrm{cm}^{2} \cdot \mathrm{m}\right)\end{array}$ & 2410.843 & 304159.118 & 63408.349 & 15642.604 & 85678.073 & 7340732224.959 \\
\hline $\begin{array}{c}\mathrm{D}_{0.1^{2}} \cdot \mathrm{H} \\
\left(\mathrm{cm}^{2} \cdot \mathrm{m}\right)\end{array}$ & 2523.758 & 305045.487 & 64015.480 & 15734.534 & 86181.595 & 7427267399.878 \\
\hline$V\left(\mathrm{~cm}^{3}\right)$ & 17343.195 & 681236.500 & 200582.988 & 42022.986 & 230169.377 & 52977942158.195 \\
\hline
\end{tabular}

D: diameter; H: height ; V: Stem volume

\section{RESULTS}

Various allometric equations were developed for the data fitting. The allometric relationships of stem volume of Acer trees to $D_{1.3}$ and $D_{1.3}{ }^{2}$ are illustrated in Figure 2 . The scatter plot shows a non-linear trend when $\mathrm{D}_{1.3}$ is used as independent variable. This trend is not changed to distribution if $\mathrm{D}_{1.3}{ }^{2}$ is used (Figure 2). This is also illustrated by the coefficient of determination using $D$, where the cubic equation $\left(R^{2}=0.963\right)$ shows a better fitting than the quadratic equation $\left(R^{2}=0.949\right)$ and power equation $\left(R^{2}=0.942\right)$. When $D_{1.3}$ values are squared, the linear equation shows a stronger relationship $\left(R^{2}=0.946\right)$ than the power equation $\left(R^{2}=0.942\right)$ and quadratic equation $\left(R^{2}=0.957\right.$ - Table 4$)$. The cubic equation $\left(R^{2}=0.963\right)$ has a stronger relationship $\left(R^{2}=0.969\right)$. In this case, the polynomial cubic equation showed the best fit for both $D_{1.3}\left(R^{2}=0.963\right)$ and $D_{1.3}{ }^{2}\left(R^{2}=0.969\right.$ - Table 4$)$ with a very close estimate by the quadratic equation for $D_{1.3}\left(R^{2}=0.949\right)$ and $D_{1.3}{ }^{2}\left(R^{2}=0.957\right)$.
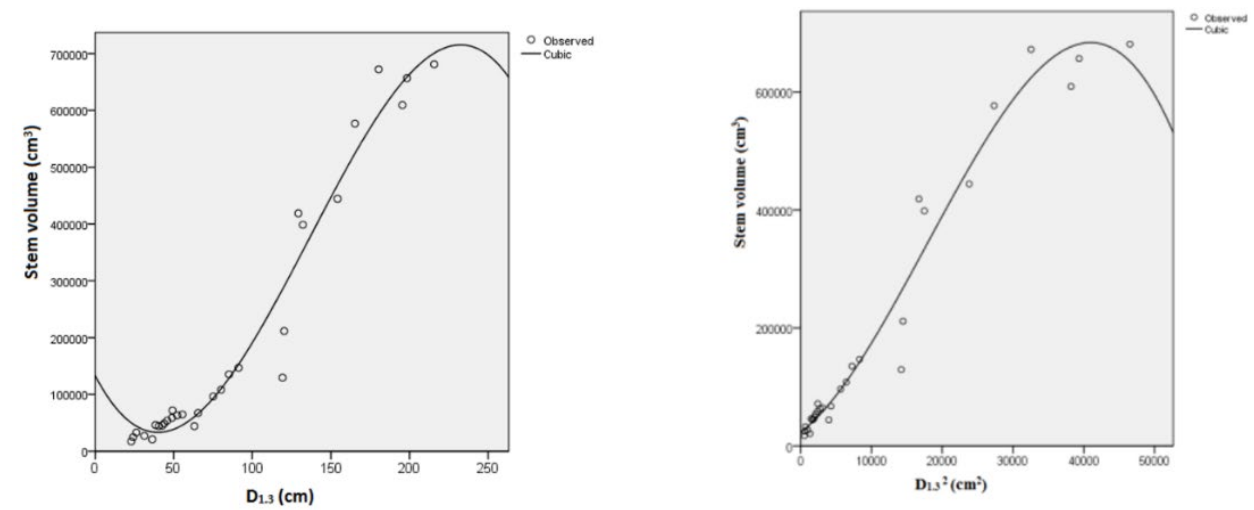

Figure 2. Relationships of stem volume to $D_{1.3}$ and $D_{1.3}{ }^{2}$ in Montpellier Maple (Acer monspessulanum) trees. 
Table 4. Summarized coefficients of the relationships between individual tree volumes of Montpellier Maple (Acer monspessulanum) to different independent variables. $H$ : Tree height; D0.1: stem diameter at a height of $\mathrm{H} / 10$; $\mathrm{D}$ : stem diameter at $1.3 \mathrm{~m}$ height (dbh). The units: $\mathrm{D}=[\mathrm{cm}], \mathrm{D} 0.1=[\mathrm{cm}], \mathrm{H}=[\mathrm{m}]$. $\mathrm{LIN}=$ Linear, $\mathrm{LOG}=$ Logarithmic, INV=Inverse, QUA = Quadratic, CUB = Cubic, COM = Compound, POW $=$ Power, $\mathrm{SIG}=$ S-curve,$G R O=$ Growth, EXP $=$ Exponential.

\begin{tabular}{|c|c|c|c|c|c|c|c|c|c|}
\hline Variable & Equation & $\mathbf{a}$ & b & c & d & $\mathbf{R}^{2}$ & $\mathbf{F}$ & Sign. & $\mathbf{R}^{2}{ }_{\text {adj }}$ \\
\hline \multirow{10}{*}{$D_{1.3}$} & LIN & -130230.78 & 3774.97 & - & - & 0.926 & 348.573 & $<0.001$ & 0.923 \\
\hline & LOG & -1073652.28 & 299393.88 & - & - & 0.774 & 95.948 & $<0.001$ & 0.766 \\
\hline & INV & 462665.63 & -15017965.36 & - & - & 0.523 & 30.718 & $<0.001$ & 0.506 \\
\hline & QUA & -24666.47 & 1012,64 & 12,40 & - & 0.949 & 249.800 & $<0.001$ & 0.945 \\
\hline & CUB & 133388.92 & $-5319,90$ & 78,06 & $-0,19$ & 0.963 & 226.615 & $<0.001$ & 0.959 \\
\hline & COM & 19804.46 & 1,01 & - & - & 0.929 & 364.468 & $<0.001$ & 0.926 \\
\hline & POW & 88.38 & 1,66 & - & - & 0.942 & 455.666 & $<0.001$ & 0.940 \\
\hline & SIG & 13.19 & -93.27 & - & - & 0.795 & 108.771 & $<0.001$ & 0.788 \\
\hline & GRO & 9.89 & 0.019 & - & - & 0.929 & 364.468 & $<0.001$ & 0.926 \\
\hline & EXP & 19804.46 & 0.019 & - & - & 0.929 & 364.468 & $<0.001$ & 0.926 \\
\hline \multirow{10}{*}{$D_{1.3^{2}}$} & LIN & 16259.45 & 16.74 & - & - & 0.946 & 488.259 & $<0.001$ & 0.944 \\
\hline & LOG & -1073652.28 & 149696.94 & - & - & 0.774 & 95.948 & $<0.001$ & 0.766 \\
\hline & INV & 309051.22 & -256223385.69 & - & - & 0.312 & 12.713 & $<0.001$ & 0.288 \\
\hline & QUA & -6459.85 & 23.02 & 0.001 & - & 0.957 & 299.127 & $<0.001$ & 0.954 \\
\hline & CUB & 23156.12 & 9.15 & 0.001 & $\begin{array}{c}-1.377 E- \\
8\end{array}$ & 0.969 & 269.283 & $<0.001$ & 0.965 \\
\hline & COM & 44232.22 & 1.00 & - & - & 0.822 & 129.244 & $<0.001$ & 0.816 \\
\hline & POW & 88.38 & 0.83 & - & - & 0.942 & 455.666 & $<0.001$ & 0.940 \\
\hline & SIG & 12.31 & -1767.04 & - & - & 0.585 & 39.515 & $<0.001$ & 0.570 \\
\hline & GRO & 10.69 & $7.865 E-5$ & - & - & 0.822 & 129.244 & $<0.001$ & 0.816 \\
\hline & EXP & 44232.22 & $7.865 E-5$ & - & - & 0.822 & 129.244 & $<0.001$ & 0.816 \\
\hline
\end{tabular}

Figure 3 illustrates the allometric relationships of stem volume to $D_{0.1}$ and $D_{0.1}{ }^{2}$. As observed with the variable $D_{1.3}$, the use of $D_{0.1}$ also showed strong data fitting $\left(R^{2}=0.924\right)$ in the allometry (Table 5). This relationship is further improved $\left(R^{2}=0.946\right)$ when the $D_{0.1}$ value is squared. The power equation for both the variables $D_{0.1}$ and $D_{0.1}{ }^{2}$ showed the same coefficient of determination $\left(R^{2}=0.942\right)$. For both the variables $D_{0.1}$ and $D_{0.1}{ }^{2}$ the polynomial cubic and quadratic equations showed a stronger fitting (Table 5) in comparison with other equations. As illustrated in Figure 4, the incorporation of tree height $\mathrm{H}$ in the allometric equation did not yield a better fitting in the linear equation, specially for both $D_{1.3}{ }^{2} H\left(R^{2}=0.919\right)$ and $D_{0.1}{ }^{2} H\left(R^{2}=0.919\right)$.

Table 5. Summarized coefficients of the relationships between individual tree volumes of Montpellier Maple (Acer monspessulanum) to different independent variables. $H$ : Tree height; $\mathrm{D}_{0.1}$ : stem diameter at a height of $H / 10 ; D_{1.3}$ : stem diameter at $1.3 \mathrm{~m}$ height (dbh). The units: $D=[\mathrm{cm}], D_{0.1}=[\mathrm{cm}], H=[\mathrm{m}]$. $\mathrm{LIN}=$ Linear, $\mathrm{LOG}=$ Logarithmic, INV=Inverse,QUA = Quadratic, CUB = Cubic, COM = Compound, POW $=$ Power, SIG = S-curve, GRO = Growth, EXP = Exponential.

\begin{tabular}{|c|c|c|c|c|c|c|c|c|c|}
\hline Variable & Equation & $\mathbf{a}$ & b & c & d & $\mathbf{R}^{2}$ & $\mathbf{F}$ & Sign. & $\mathbf{R}^{2}$ adj \\
\hline \multirow{10}{*}{$\mathrm{D}_{0.1}$} & LIN & 3767.93 & -131830.14 & - & - & 0.924 & 342.996 & $<0.001$ & 0.922 \\
\hline & LOG & -1083894.16 & 301151.54 & - & - & 0.774 & 95.817 & $<0.001$ & 0.766 \\
\hline & INV & 464530.30 & -15300882.817 & - & - & 0.525 & 30.893 & $<0.001$ & 0.508 \\
\hline & QUA & -24270.37 & 976.782 & 12,473 & - & 0.948 & 245.988 & $<0.001$ & 0.944 \\
\hline & CUB & 135906.44 & -5387.508 & 78,115 & $-0,190$ & 0.962 & 221.026 & $<0.001$ & 0.958 \\
\hline & COM & 19629.31 & 1.019 & - & - & 0.928 & 363.255 & $<0.001$ & 0.926 \\
\hline & POW & 83.65 & 1.673 & - & - & 0.942 & 449.014 & $<0.001$ & 0.939 \\
\hline & SIG & 13.2 & $-94,917$ & - & - & 0.796 & 108.943 & $<0.001$ & 0.788 \\
\hline & GRO & 9.855 & 0.019 & - & - & 0.928 & 363.255 & $<0.001$ & 0.926 \\
\hline & EXP & 19629.316 & 0.019 & - & - & 0.928 & 363.255 & $<0.001$ & 0.926 \\
\hline
\end{tabular}


Stem volume estimate using an allometric equation model: a case study of Acer monspessulanum stands in Tunisia

Table 5. Continued...

\begin{tabular}{|c|c|c|c|c|c|c|c|c|c|}
\hline Variable & Equation & a & b & c & d & $\mathbf{R}^{2}$ & $\mathbf{F}$ & Sign. & $\mathbf{R}^{2}$ adj \\
\hline \multirow{10}{*}{$\mathrm{D}_{0.1^{2}}$} & LIN & 16259.45 & 16.74 & - & - & 0.946 & 488.259 & $<0.001$ & 0.934 \\
\hline & LOG & -1073652.28 & 149696.94 & - & - & 0.774 & 95.948 & $<0.001$ & 0.766 \\
\hline & INV & 309051.22 & -256223386 & - & - & 0.312 & 12.713 & $<0.001$ & 0.289 \\
\hline & QUA & -6459.85 & 23.025 & 0.001 & - & 0.957 & 299.127 & $<0.001$ & 0.953 \\
\hline & CUB & 23156.12 & 9.15 & 0.001 & $-1.377 E-8$ & 0.968 & 269.283 & $<0.001$ & 0.964 \\
\hline & COM & 44232.22 & 1.00 & - & - & 0.822 & 129.244 & $<0.001$ & 0.817 \\
\hline & POW & 88.38 & 0.832 & - & - & 0.942 & 455.666 & $<0.001$ & 0.939 \\
\hline & SIG & 12.31 & -1767.04 & - & - & 0.585 & 39.515 & $<0.001$ & 0.571 \\
\hline & GRO & 10.69 & $7.865 E-5$ & - & - & 0.822 & 129.244 & $<0.001$ & 0.817 \\
\hline & EXP & 44232.22 & $7.865 E-5$ & - & - & 0.822 & 129.244 & $<0.001$ & 0.817 \\
\hline
\end{tabular}
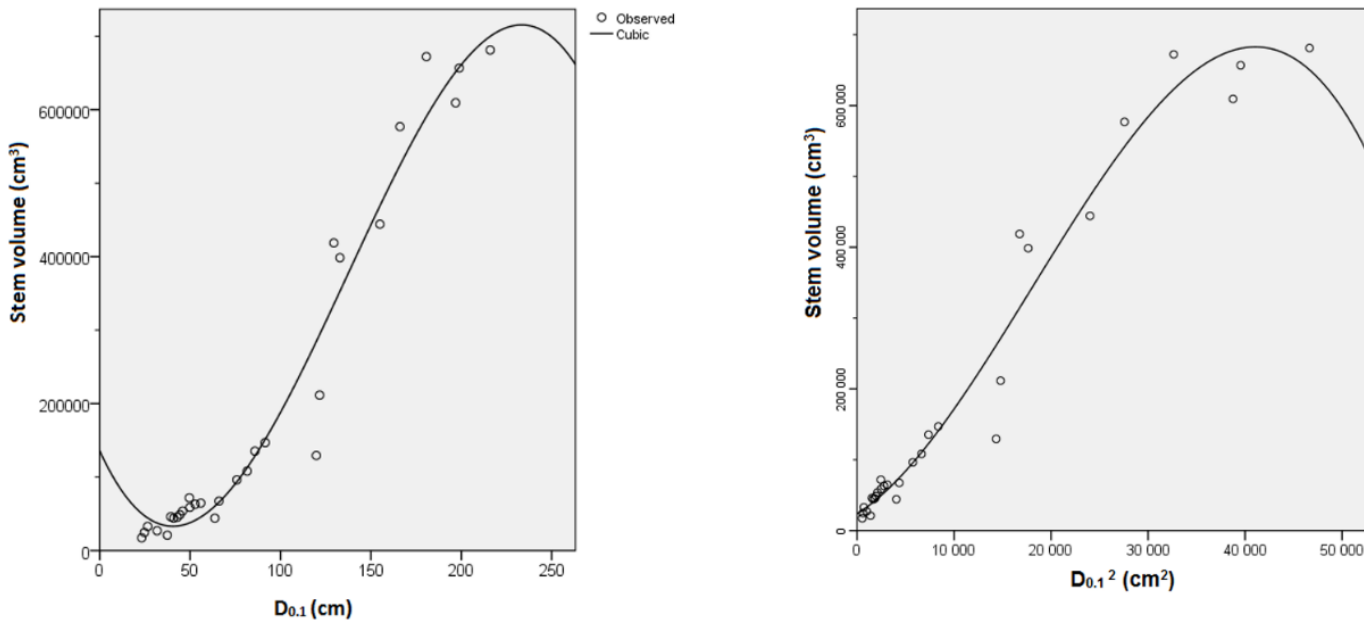

Figure 3. Relationships of stem volume to $\mathrm{D}_{0.1}$ and $\mathrm{D}_{0.1}{ }^{2}$ in Montpellier Maple (Acer monspessulanum) trees.
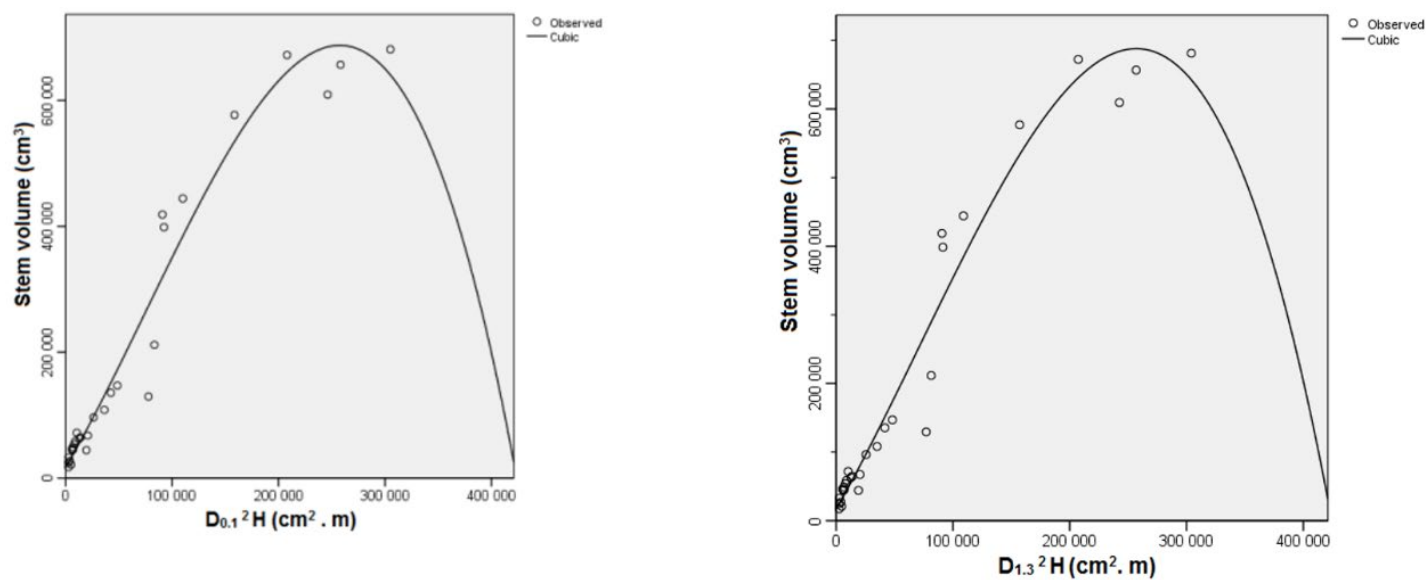

Figure 4. Relationships of stem volume to $\mathrm{D}_{1.3}{ }^{2} \mathrm{H}$ and $\mathrm{D}_{0.1}{ }^{2} \mathrm{H}$ in Montpellier Maple (Acer monspessulanum) trees.

The polynomial cubic along with the quadratic equation showed a very close fit in comparison with the linear equation for both variables $D_{1.3}{ }^{2} \mathrm{H}$ and $\mathrm{D}_{0.1}{ }^{2} \mathrm{H}$ (Table 6 and Figure 4). It can be clearly seen for the Figure 2 and Table 3 that $D_{1.3}{ }^{2}$ has a stronger relationship than $D_{1.3}$ when used as an independent variable. This is further emphasized by the coefficient of determination $\left(R^{2}\right)$, as the $R^{2}$ value of $D_{1.3}{ }^{2}\left(R^{2}=0.969\right)$ is greater than the $R^{2}$ value of $D_{1.3}\left(R^{2}=0.963\right)$.

Figure 5 presents residues, observed and estimated values of the residues of the fied cubic model at $\mathrm{D}_{1.3}{ }^{2}(\mathrm{DBH})$ and Figure 6 represents residues, observed and estimated values of the residues of the fied cubic model at $D_{0.1}{ }^{2}$. This figure shows that the normality of residues 
can be considered as having been respected. The residuals are randomly distributed around the zero value depending on volumes or diameter (Figure 5 and 6 ). The cubic model is the best model used to estimate the volume of trees based on the parameters $D_{1.3}{ }^{2}(\mathrm{DBH})$ and $\mathrm{D}_{0.1}{ }^{2}$.
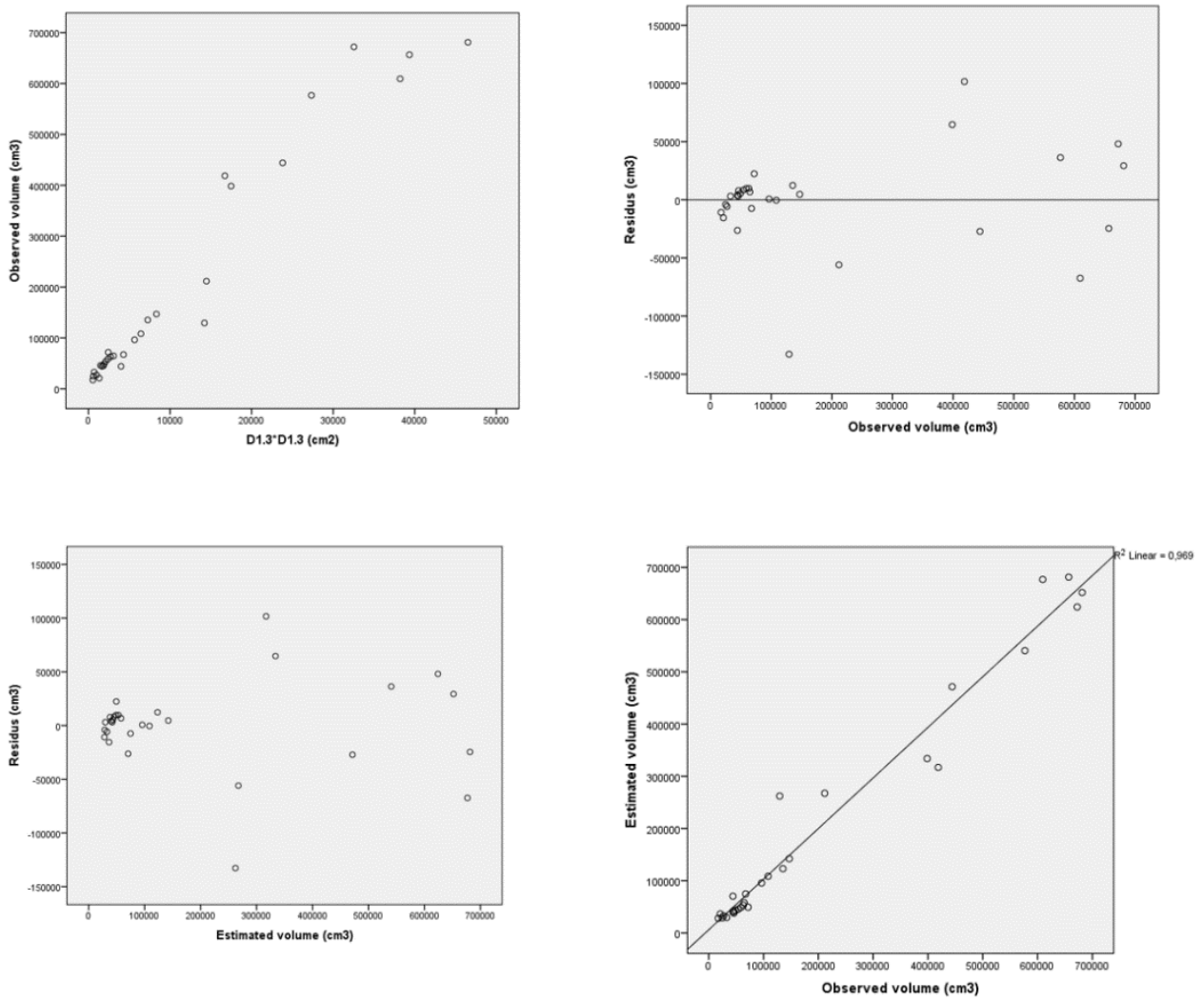

Figure 5. Residues, observed and estimated values of the residues of the fied cubic model $\left(D_{1.3^{2}}\right)$.
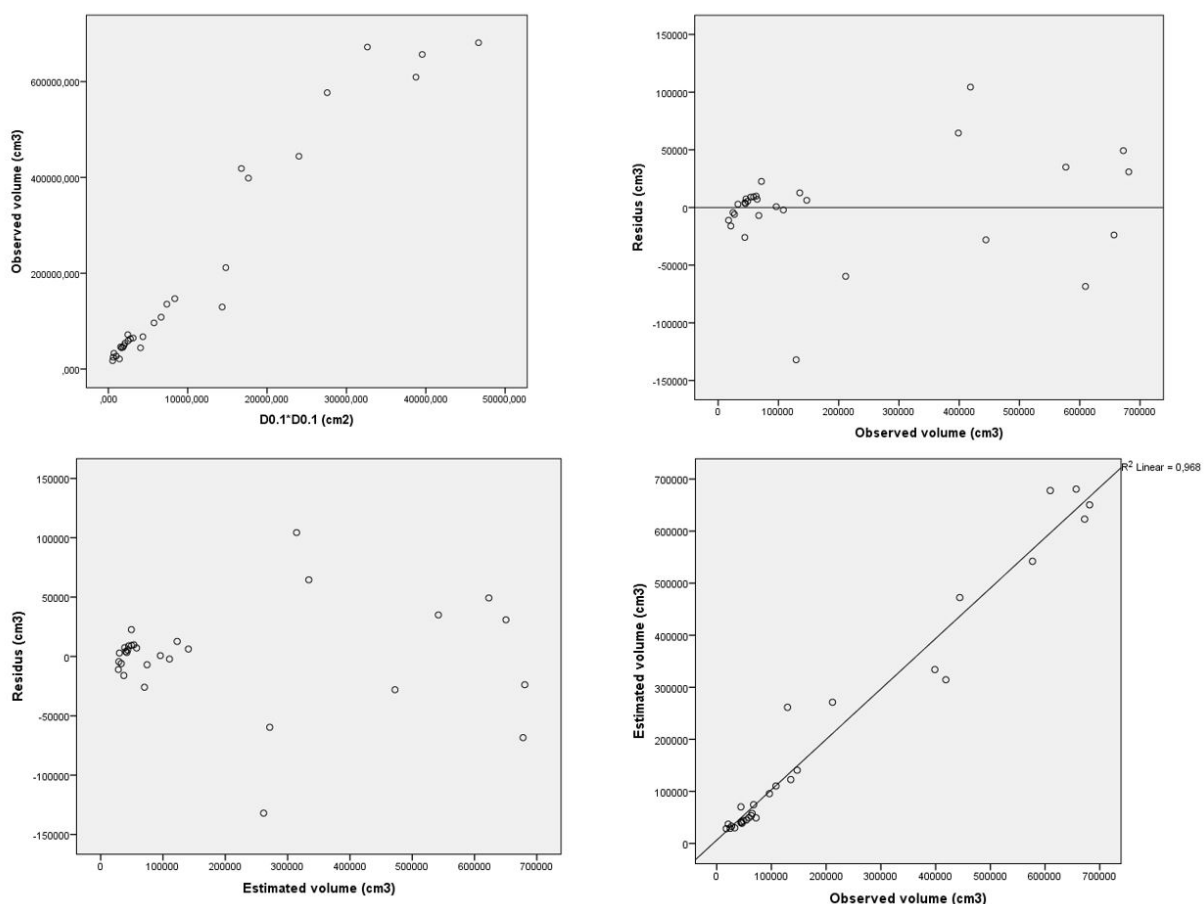

Figure 6. Residues, observed and estimated values of the residues of the fied cubic model $\left(\mathrm{D}_{0.1}{ }^{2}\right)$. 


\section{DISCUSSION}

Although the allometric equations were highly significant $(P<0.01)$ there was considerable variation among them as indicated by the coefficient of determination $R^{2}$ values (Table 4: Table 5 and Table 6). The scatter plotting (Figure 2) shows a non-linear trend for $D_{1.3}$ as independent variable, which becomes non-linear when plotted against $D_{1.3}{ }^{2}$. This indicates that tree volume is more correlated with basal area than with simple dbh (Burrows et al., 2000). Using the simple $D_{1.3}$ as independent variable in the allometric equation, the cubic equation showed the best fit $\left(R^{2}=0.963\right)$ with a very close estimate by the quadratic equation $\left(R^{2}=0.949\right)$. However, there were low differences in the goodness-of-fit among the polynomial, power and linear equations.

Table 6. Summarized coefficients of the relationships between individual tree volumes of Montpellier Maple (Acer monspessulanum) to different independent variables. $H$ : Tree height; D0.1: stem diameter at a height of H/10; $D$ : stem diameter at $1.3 \mathrm{~m}$ height (dbh). The units: $\mathrm{D}=[\mathrm{cm}], \mathrm{D} 0.1=[\mathrm{cm}], \mathrm{H}=[\mathrm{m}]$. $\mathrm{LIN}=$ Linear, $\mathrm{LOG}=$ Logarithmic, $\mathrm{INV}=$ Inverse, $\mathrm{QUA}=$ Quadratic, $\mathrm{CUB}=$ Cubic, $\mathrm{COM}=$ Compound, $\mathrm{POW}=$ Power, $\mathrm{SIG}=$ S-curve, $\mathrm{GRO}=$ Growth, EXP $=$ Exponential.

\begin{tabular}{|c|c|c|c|c|c|c|c|c|c|}
\hline Variable & Equation & $a$ & b & c & d & $\mathbf{R}^{2}$ & $\mathbf{F}$ & Sign. & $\mathbf{R}^{2}{ }_{\text {adj }}$ \\
\hline \multirow{9}{*}{$\mathrm{D}_{1.3}{ }^{2} \mathrm{H}$} & LIN & 37290.004 & 2.575 & - & - & 0.919 & 317.417 & $<0.001$ & 0.916 \\
\hline & LOG & -1142880.32 & 133445.05 & - & - & 0.778 & 98.243 & $<0.001$ & 0.770 \\
\hline & INV & 313393.86 & -1106018467 & - & - & 0.334 & 14.012 & $<0.001$ & 0.310 \\
\hline & QUA & 2276.18 & 4.28 & $-6.628 \mathrm{E}-6$ & - & 0.955 & 284.236 & $<0.001$ & 0.951 \\
\hline & CUB & 16671.861 & 2.98 & $7.230 \mathrm{E}-6$ & $\begin{array}{c}-3.383 \mathrm{E}- \\
11\end{array}$ & 0.961 & 211.141 & $<0.001$ & 0.956 \\
\hline & COM & 49591.557 & 1.00 & - & - & 0.766 & 91.884 & $<0.001$ & 0.758 \\
\hline & POW & 62.58 & 0.73 & - & - & 0.937 & 416.974 & $<0.001$ & 0.935 \\
\hline & SIG & 12.33 & -7563.24 & - & - & 0.615 & 44.655 & $<0.001$ & 0.601 \\
\hline & GRO & 10.81 & $1.185 \mathrm{E}-5$ & - & - & 0.766 & 91.884 & $<0.001$ & 0.758 \\
\hline \multirow{11}{*}{$\mathrm{D}_{0.1^{2}} \mathrm{H}$} & EXP & 49591.55 & $1.185 \mathrm{E}-5$ & - & - & 0.766 & 91.884 & $<0.001$ & 0.758 \\
\hline & LIN & 36707.16 & 2.56 & - & - & 0.919 & 316.583 & $<0.001$ & 0.916 \\
\hline & LOG & -1152409.58 & 134147.23 & - & - & 0.778 & 98.147 & $<0.001$ & 0.770 \\
\hline & INV & 314354.31 & -1145863312.23 & - & - & 0.336 & 14.150 & $<0.001$ & 0.312 \\
\hline & QUA & 1815.40 & 4.29 & $-6.494 \mathrm{E}-6$ & - & 0.954 & 277.568 & $<0.001$ & 0.950 \\
\hline & CUB & 16822.63 & 2.90 & $7.796 \mathrm{E}-6$ & $\begin{array}{c}-3.480 \mathrm{E}- \\
11\end{array}$ & 0.960 & 207.461 & $<0.001$ & 0.955 \\
\hline & $\mathrm{COM}$ & 49428.96 & 1.00 & - & - & 0.768 & 92.431 & $<0.001$ & 0.759 \\
\hline & POW & 59.49 & 0.74 & - & - & 0.936 & 411.988 & $<0.001$ & 0.934 \\
\hline & SIG & 12.33 & -7821.02 & - & - & 0.616 & 44.981 & $<0.001$ & 0.603 \\
\hline & GRO & 10.80 & $1.179 \mathrm{E}-5$ & - & - & 0.768 & 92.431 & $<0.001$ & 0.759 \\
\hline & EXP & 49428.96 & $1.179 E-5$ & - & - & 0.768 & 92.431 & $<0.001$ & 0.759 \\
\hline
\end{tabular}

The cubic polynomial as well as the quadratic equation showed strong fitting for both variables $D_{1.3}$ and $D_{1.3}{ }^{2}$ with respect to other equations, with an $R^{2}$ value of $D_{1.3}{ }^{2}$ and $D_{1.3}$ (0.9441). Hence $D_{1.3^{2}}$, which represents the independent variable should be more considered suitable than $D_{1.3}$. As the quadratic and cubic equations consist of several coefficients, for practical applications in stand volume estimation, because of simplicity, the linear or power equations over the use of $D_{1.3}{ }^{2}$ as an independent variable should be preferred (Khan et al., 2005; Khan \& Faruque, 2010).

Like the commonly known variable $D$, the use of $D_{0.1}$ also showed strong linear data fitting $\left(R^{2}=0.924\right)$ in the allometry (Table 5$)$. This degree of linearity was further improved $\left(R^{2}=0.946\right)$ when the $D_{0.1}{ }^{2}$ value was used instead of $D_{0.1}$ (Hagihara et al., 1993; Khan et al., 2005; Khan \& Faruque, 2010). Here, the cubic equation showed the best fit for both $D_{0.1}\left(R^{2}=0.962\right)$ and $D_{0.1}{ }^{2}$ $\left(R^{2}=0.969\right) . D_{0.1}^{2}$ showed a stronger relationship than $D_{0.1}$ when used as an independent 
variable. This was further explained by $R^{2}$ (coefficient of determination) i.e. the value of $R^{2}$ of $D_{0.1}{ }^{2}\left(R^{2}=0.969\right)$ was greater than $D_{0.1}\left(R^{2}=0.962\right)$. The next strong fit was also from the quadratic equation for $D_{0.1}\left(R^{2}=0.948\right)$ and $D_{0.1}{ }^{2}\left(R^{2}=0.957\right)$. Overall, it may be remarked that the allometric relationships of stem volume to the tree diameter at $10 \%$ of tree height $\left(D_{0.1}\right)$ did not improve in a clear way the allometric strength in Acer in comparison with simple $D_{1.3}$ as reported in some tree species (Khan \& Faruque, 2010; Hagihara et al., 1993; Khan et al., 2005).

Thus, it can be inferred that the Polynomial Cubic Equation was best fitted for both $D_{0.1}$ $\left(R^{2}=0.962\right)$ and $D_{0.1}{ }^{2}\left(R^{2}=0.969\right)$ than any other equation and the degree of linearity can be further enhanced using $D_{0.1}{ }^{2}$ in place of the $D_{0.1}$ value. From the above findings we can derive that the polynomial cubic equation showed a close fit as compared to the quadratic equation. The multiplication of tree height $\mathrm{H}$ with diameter or basal area in the allometric equation gives a high degree of linearity for both the variables $D_{1.3}{ }^{2} H\left(R^{2}=0.926\right)$ and $D_{0.1}{ }^{2} H$ $\left(R^{2}=0.946\right)$ in the allometric estimation.

It was further evident from the scatter plot that both $D_{0.1}{ }^{2}\left(R^{2}=0.946\right)$ and $D_{0.1}{ }^{2} H$ $\left(R^{2}=0.919\right)$ were best fitted in the linear equation and could be determined by the evolving tree height. This suggests that biologically tree diameter and height change proportionality with the change of tree size (Khan et al., 2005; Khan \& Faruque, 2010). Hence, H is incorporated in the allometric equations, the polynomial cubic and quadratic equations showed an almost similar degree of fitting in comparison with linear equation for both the variables $\mathrm{D}_{1.3}{ }^{2} \mathrm{H}$ and $\mathrm{D}_{0.1}{ }^{2} \mathrm{H}$, because of simplicity, the linear equation would be preferred for indirect estimation in the field with a good level of accuracy $\left(R^{2}=0.946 ; R^{2}=0.926\right)$. For predicting timber yield (Madgwick et al., 1991) foresters often combine trunk diameter and height measurements (Madgwick et al., 1991; Avery \& Burkhart, 1994) as the independent variables in allometric relationships. However, for the Acer tree studied the stem dbh alone showed a very strong accuracy of estimation ( $R^{2}=0.946$ to 0.969$)$ especially when used as $D_{1.3}{ }^{2}$. Thus, it is concluded that the use of tree height in the allometric equation (Suzuki \& Tagawa, 1983; Kusmana et al., 1992; Poungparn et al., 2002; Khan et al., 2005; Khan \& Faruque, 2010) can be neglected for Acer, as far as the present study area is concerned. Therefore, for estimating the stem volume of Acer, the use of $D_{1.3}{ }^{2}$ as an independent variable in the allometric equation with a linear or cubic equation is recommended.

The findings of this study indicate that there is a variation in the use of independent variables in allometric equations for estimating the stem volume of the species. The allometric relationships described are not appropriate in mixed or open forest stands (Khan \& Faruque, 2010), because the present study was carried out under monospecific conditions. For the estimation of stem volume of trees outside the size range of this investigation, care should be taken in extrapolating the present allometric relationships. Therefore, we recommend that users of these allometric equations check some individual trees outside the present size class.

\section{CONCLUSION}

The allometric relationships of stem volume of Acer trees to $D_{1.3}$ and $D_{1.3}{ }^{2}$ shows a nonlinear trend when $D_{1.3}$ is used as independent variable. This distribution trend is not changed if $D_{1.3}{ }^{2}$ is used. The cubic equation $\left(R^{2}=0.963\right)$ has a stronger relationship $\left(R^{2}=0.969\right)$. The polynomial cubic equation showed the best fit for both $D_{1.3}\left(R^{2}=0.963\right)$ and $D_{1.3}{ }^{2}\left(R^{2}=0.969\right)$ with a very close estimate by the quadratic equation for $D_{1.3}\left(R^{2}=0.949\right)$ and $D_{1.3}{ }^{2}\left(R^{2}=0.957\right)$. The power equation for both the variables $D_{0.1}$ and $D_{0.1}{ }^{2}$ showed the same coefficient of determination $\left(R^{2}=0.942\right)$. For both the variables $D_{0.1}$ and $D_{0.1}{ }^{2}$ the polynomial cubic and quadratic equations showed a stronger fitting. This allometric model was highly significant with $p$-value $<0.01$ and showed strong correlation of stem volume with the product of diameter and height. Hence, $D_{1.3}{ }^{2}$ is preferred as an independent variable for stand volume investigation. 


\section{ACKNOWLEDGEMENTS}

We are grateful to the Sylvo-Pastoral Institute of Tabarka in Tunisia for providing logistic support for the field data collection. The data analysis and manuscript preparation were performed in the laboratory of Forest Ecology, in National Research Institute of Rural Engineering, Water, and Forestry in Tunisia. We thank the conservative and the manager of Jebel Serej National Park for his enthusiasm and collaboration during the field work and we are grateful to all members of the CRDA Siliana in Tunisia for technical assistance rendered. The anonymous reviewers are thanked for their constructive remarks and suggestions.

\section{REFERENCES}

Akindele, S. O., \& LeMay, V. M. (2006). Development of tree volume equations for common timber species in the tropical rain forest area of Nigeria. Forest Ecology and Management, 226(1-3), 41-48. http://dx.doi.org/10.1016/j.foreco.2006.01.022.

Amarasinghe, M. D., \& Balasubramaniam, S. (1992). Net primary productivity of two mangrove forests stands on the northwest coast of Sri Lanka. Hydrobiologia, 247(1-3), 37-47. http://dx.doi.org/10.1007/BF00008203.

Avery, T. E., \& Burkhart, H. E. (1994). Forest measurements ( pp. 408). New York: McGraw-Hill.

Baker, T. R., Phillips, O. L., Malhi, Y., Almeida, S., Arroyo, L., Di Fiore, A., Killeen, T. J., Laurance, S. G., Laurance, W. F., Lewis, S. L., Lloyd, J., Monteagudo, A., Neill, D. A., Patiño, S., Pitman, N. C. A., Silva, N., \& Martínez, R. V. (2004). Variation in wood density determines spatial patterns in Amazonian forest biomass. Global Change Biology, 10(5), 545-562. http://dx.doi.org/10.1111/j.13652486.2004.00751.x.

Burrows, W. H., Hoffmann, M. B., Compton, J. F., Back, P. V., \& Tait, L. J. (2000). Allometric relationships and community biomass estimates for some dominant eucalypts in Central Queensland woodlands. Australian Journal of Botany, 48(6), 707-714. http://dx.doi.org/10.1071/BT99066.

Chave, J., Andalo, C., Brown, S., Cairns, M. A., Chambers, J. Q., Eamus, D., Fölster, H., Fromard, F., Higuchi, N., Kira, T., Lescure, J. P., Nelson, B. W., Ogawa, H., Puig, H., Riéra, B., \& Yamakura, T. (2005). Tree allometry and improved estimation of carbon stocks and balance in tropical forests. Oecologia, 145(1), 87-99. PMid:15971085. http://dx.doi.org/10.1007/s00442-005-0100-x.

Clough, B. F., Dixon, P., \& Dalhaus, O. (1997). Allometric relationships for estimating biomass in multistemed mangrove trees. Australian Journal of Botany, 45(6), 1023-1031. http://dx.doi.org/10.1071/BT96075.

Clough, B. F., \& Scott, K. (1989). Allometric relationships for estimating above ground biomass in six mangroves species. Forest Ecology and Management, 27(2), 117-127. http://dx.doi.org/10.1016/03781127(89)90034-0.

Cowett, F. D., \& Bassuk, N. L. (2014). Statewide assessment of street trees in New York State, USA. Urban Forestry \& Urban Greening, 13(2), 213-220. http://dx.doi.org/10.1016/j.ufug.2014.02.001.

Dirr, M. A. (2009). Manual of woody landscape plants (6th ed.). Champaign, IL: Stipes Publishing L.L.C.

Grimshaw, J., \& Bayton, R. (2009). New trees: recent introductions to cultivation. Kew: International Dendrology Society, Royal Botanic Garden; Kew Publishing.

Hagihara, A., Yokota, T., \& Ogawa, K. (1993). Allometric relations in hinoki (Chamaecyparisobtusa (Sieb. et Zucc.) Endl.). Trees. Bulletin of Nagoya University Forestry, 12, 11-29.

Ketterings, Q. M., Coe, R., Van Noordwijk, M., Ambagau', Y., \& Palm, C. A. (2001). Reducing uncertainty in the use of allometric biomass equations for predicting above ground tree biomass in mixed secondary forest. Forest Ecology and Management, 146(1-3), 199-209. http://dx.doi.org/10.1016/S0378-1127(00)00460-6.

Khan, M. N. I., \& Faruque, O. (2010). Allometric relationships for predicting the stem volume in a Dalbergia sissoo Roxb. Plantation in Bangladesh. iForest - Biogeosciences and Forestry, 3(6), 153-158. http://dx.doi.org/10.3832/ifor0554-003.

Khan, M. N. I., Suwa, R., \& Hagihara, A. (2005). Allometric relationships for estimating the aboveground phytomass and leaf area of mangrove Kandelia candal (L.) Druce trees in the Manko Wetland, Okinawa Island, Japan. Trees, 19(3), 266-272. http://dx.doi.org/10.1007/s00468-004-0377-0.

Kusmana, C., Sabiham, S., Abe, K., \& Watanabe, H. (1992). An estimation of above ground tree biomass of the mangrove forest in East Sumatra, Indonesia. Tropics, 1(4), 243-257.

http://dx.doi.org/10.3759/tropics.1.243. 
Kvalseth, T. O. (1983). Rank-frequency distribution of accident statistics. Journal of Safety Research, 14(4), 173-181. http://dx.doi.org/10.1016/0022-4375(83)90045-2.

Li, L., Manning, W. J., Tong, L., \& Wang, X. (2015). Chronic drought stress reduced but not protected Shantung maple (Acer truncatum Bunge) from adverse effects of ozone (O3) on growth and physiology in the suburb of Beijing, China. Environmental Pollution, 201, 34-41. PMid:25765971. http://dx.doi.org/10.1016/j.envpol.2015.02.023.

Lumbers, R. I., Abino, A. C., \& Pampolina, N. M. (2016). Comparison of stem taper models for the four tropical tree species in Mount Makiling, Philippines. Journal of Mountain Science, 13(3), 536-545. http://dx.doi.org/10.1007/s11629-015-3546-2.

Madgwick, H. A. I., Frederick, D. J., \& Tew, D. T. (1991). Biomass relationships in stands of Eucalyptus species. Bioresource Technology, 37(1), 85-91. http://dx.doi.org/10.1016/0960-8524(91)90115-Z.

Malhi, Y., Wood, D., Baker, T. R., Wright, J., Phillips, O. L., Cochrane, T., Meir, P., Chave, J., Almeida, S., Arroyo, L., Higuchi, N., Killeen, T., Laurance, S. G., Laurance, W. F., Lewis, S. L., Monteagudo, A., Neill, D. A., Vargas, P. N., Pitman, N. C. A., Quesada, C. A., Salomão, R., Silva, J. N. M., Lezama, A. T., Terborgh, J., Martínez, R. V., \& Vinceti, B. (2006). The regional variation of aboveground live biomass in oldgrowth Amazonian forests. Global Change Biology, 12(7), 1107-1138. http://dx.doi.org/10.1111/j.1365-2486.2006.01120.x.

Mechergui, K., Jaouadi, W., \& Khouja, M. (2018). Dendroecology of Montpellier maple's population (Acer monspessulanum) from the North Africa region: analysis of maple stations characteristics and natural habitat. Plant Biosystems, 152(1), 98-109. http://dx.doi.org/10.1080/11263504.2016.1255269.

Nakasuga, T. (1979). Analysis of mangrove stands. Japanese Journal of Ecology, 24, 237-246.

Nogueira, E. M., Fearnside, P. M., Nelson, B. W., Barbosa, R. I., \& Keizer, E. W. H. (2008). Estimates of forest biomass in the Brazilian Amazon: new allometric equations and adjustments to biomass from wood-volume inventories. Forest Ecology and Management, 256(11), 1853-1867. http://dx.doi.org/10.1016/j.foreco.2008.07.022.

Ogawa, H., \& Kira, T. (1977). Methods of estimating forest biomass. In T. Shidei \& T. Kira (Eds.), Primary productivity of Japanese forests: productivity of terrestrial communites (pp. 15-36). Tokyo: University of Tokyo Press.

Ong, J. E., Gong, W. K., \& Wong, C. H. (2004). Allometry and partitioning of the mangrove, Rhizophora apiculata. Forest Ecology and Management, 188(1-3), 395-408. http://dx.doi.org/10.1016/j.foreco.2003.08.002.

Pagaduan, D. C., \& Afuang, L. E. (2012). Understorey bird species diversity along elevational gradients on the northeastern slope of Mt. Makiling, Luzon, Philippines. Asia Life Sciences, 21(2), 585-607.

Palm, R. (1988). Les critères de validation des équations de régression linéaire (Notes de Statistique et d'Informatique, No. 1, 27 p.). Gembloux: Faculté des Sciences Agronomique.

Philip, M. S. (1994). Measuring trees and forests (2nd ed.). Wallingford: CAB International.

Poungparn, S., Komiyama, A., Patanaponpaipoon, P., Jintana, V., Sangtiean, T., Tanapermpool, P., Piriyayota, S., Maknual, C., \& Kato, S. (2002). Site independent allometric relationships for estimating above-ground weights of mangroves. Tropics, 12(2), 147-158. http://dx.doi.org/10.3759/tropics.12.147.

Putz, F. E., \& Chan, H. T. (1986). Tree growth, dynamic, and productivity in a mature mangrove forest in Malaysia. Forest Ecology and Management, 17(2-3), 211-230. http://dx.doi.org/10.1016/03781127(86)90113-1.

Raupp, M. J., Buckelew-Cumming, A., \& Raupp, E. C. (2006). Street tree diversity in eastern North America and its potential for tree loss to exotic borers. Arboriculture \& Urban Forestry, 32(6), 297 304.

Robinson, A. P., \& Wood, G. (1994). Individual tree volume estimation: a new look at new systems. Journal of Forestry, 92(12), 25-29.

Sjöman, H., Hirons, A. D., \& Bassuk, N. L. (2015). Urban forest resilience through tree selection: variation in drought tolerance in Acer. Urban Forestry \& Urban Greening, 14(4), 858-865. http://dx.doi.org/10.1016/j.ufug.2015.08.004.

Sjöman, H., Östberg, J., \& Bühler, O. (2012). Diversity and distribution of the urban tree population in ten major Nordic cities. Urban Forestry \& Urban Greening, 11(1), 31-39. http://dx.doi.org/10.1016/j.ufug.2011.09.004.

Statistical Package for the Social Science - SPSS. (2004). SPSS 23.0 for the Windows. Chicago: SPSS Inc. 
Subedi, N., Sharma, M., \& Parton, J. (2011). Effects of sample size and tree selection criteria on the performance of taper equations. Scandinavian Journal of Forest Research, 26(6), 555-567. http://dx.doi.org/10.1080/02827581.2011.583677.

Suzuki, E., \& Tagawa, H. (1983). Biomass of mangrove forest and a sedge marsh on Ishigaki island, south Japan. Japanese Journal of Ecology, 33, 231-234.

Tamai, S., Nakasuga, T., Tabuchi, R., \& Ogino, K. (1986). Standing biomass of mangrove forests in southern Thailand. Nihon Shinrin Gakkaishi, 68, 384-388.

Van Coillie, F., Delaplace, K., Gabriels, D., De Smet, K., Ouessar, M., Ouled Belgacem, A., Taamallah, H., \& De Wulf, R. (2016). Monotemporal assessmen t of the population structure of Acacia tortilis (Forssk.) Hayne ssp. raddiana (Savi) Brenan in Bou Hedma National Park, Tunisia: a terrestrial and remote sensing approach. Journal of Arid Environments, 129, 80-92. http://dx.doi.org/10.1016/j.jaridenv.2016.02.009.

Van Gelderen, D. M., de Jong, P. C., \& Oterdom, H. J. (1994). Maples of the World. Portland, OR: Timber Press.

Zohary, M. (1973). Geobotanical foundations of the Middle East (Vol. 1, 2). Stuttgart: Gustav Fischer Verlag.

Author's Contributions: WJ: performed the experiments and approved the final draft; KM and WJ conceived and designed the experiments, analyzed the data, prepared figures and/or tables, authored or reviewed drafts of the paper, approved the final draft; MA analyzed the data and contributed reagents/materials/analysis tools, approved the final draft ; SN analyzed the data, prepared figures and/or tables, authored or reviewed drafts of the paper, approved the final draft. 